\title{
Sedimentological Studies of Alluvium Deposits along Ngovayang-Bipindi of Lokoundje River, Southwestern Cameroon
}

\author{
Mioumnde Arthur Paterne ${ }^{1,2,3 *}$, Mboui Felicité Audrey Katia4, Kue Petou Rokis Malquaire ${ }^{3,5,6 *}$, \\ Kabir Shola Ahmed ${ }^{3}$, Bessong Moïse ${ }^{2}$, Liqiang Zhang1,3
}

${ }^{1}$ Key Laboratory of Deep Oil and Gas (China University of Petroleum (East China)), Qingdao, China

${ }^{2}$ Lobaratory of Ore Processing, Institute of Geological and Mining Research, Yaoundé, Cameroon

${ }^{3}$ School of Geosciences, China University of Petroleum, Qingdao, China

${ }^{4}$ Department of Biology, Advanced Teacher Training College, University of Yaoundé I, Yaoundé, Cameroon

${ }^{5}$ National Institute of Cartography, Yaoundé, Cameroon

${ }^{6}$ Postgraduate School of Sciences, Technologies \& Geosciences, University of Yaoundé I, Yaoundé, Cameroon

Email: *arthurmioumnde@yahoo.fr, *rokis.petou@yahoo.fr

How to cite this paper: Paterne, M.A. Katia, M.F.A., Malquaire, K.P.R., Ahmed, K.S., Moïse, B. and Zhang, L.Q. (2019) Sedimentological Studies of Alluvium Deposits along Ngovayang-Bipindi of Lokoundje River, Southwestern Cameroon. International Journal of Geosciences, 10, 119-139. https://doi.org/10.4236/ijg.2019.101008

Received: December 24, 2018

Accepted: January 28, 2019

Published: January 31, 2019

Copyright (c) 2019 by author(s) and Scientific Research Publishing Inc. This work is licensed under the Creative Commons Attribution International License (CC BY 4.0).

http://creativecommons.org/licenses/by/4.0/

\begin{abstract}
In an area of about $305 \mathrm{~km}^{2}$, Seventeen stream sediment samples were taken from alluvium on the banks and floodplain of the Lokoundjé River and its tributaries. Sand samples after being dried in an oven, are subjected to sedimentological analyses in laboratory. Amongst the analysis carried out; the particle size analysis helped to establish a precise textural description of the sediment and to understand the active mechanisms which occur during transport and particle deposition. The morphoscopy of quartz grains consists in determining the mode and duration of transport of the grains, thus allowing reconstructing the geological history of the latter. Heavy minerals are suitable to know the nature of the rock in which they come from and equal to specify their distributing province. The morphometry of pebble makes contributes for a better understanding to apprehension of the agents responsible for the transport of these materials. It appears that the alluvium of the Lokoundjé and its Bipindi tributaries are very fine to coarse. They are well segregated, classified, and homometric. It is the result of the actions of a hydrodynamic turbulent which is sometimes abrupt. From a morphoscopic point of view, using a binocular microscope, grains mainly belong to three categories based on their surface appearance: Grain unworn, the sub-dull and dull shiny. From the morphometric point of view, there is evidence of flattening and dissymmetry of pebbles which are slightly worn to form sub-spherical shapes. With regard to the study of heavy minerals, it has identified two mineralogical processions, which include a metamorphic process
\end{abstract}


with the presence of Sillimanite and Andalusite. In addition, there is the presence of minerals such as green's Hornblende, Tourmaline, and reflecting magmatic distribution. However, there are specific minerals such as zircon, which can be economically viable where the contents sometimes exceed 10 $\mathrm{kg} / \mathrm{m}^{3}$. In the same vein, it has been noted the presence of gems like Topaze and Monazite which are real precursor auriferous accumulation.

\section{Keywords}

Sedimentology, Alluvium Deposits, Lokoundjé River, Ngovayang-Eséka

\section{Introduction}

The study area is located in the coastal plain of Cameroon. The coastal plain is the lowest elevation zone $(0-350 \mathrm{~m})$, [1] [2] see in this plain a succession of three levels of increasing altitude from the sea to the southern plateau of Cameroon. This study is conducted with the aim of knowing the sedimentological characteristics of a coastal plain zone, which is favorable to the accumulation of the erosion materials rich in useful substances; just because it is located below a mountain range where weathering is important and the outcrops are rare because of the forest. The Ngovayang Mountain, which constitutes a dense intrusive rock [3] according to some prospecting activities, would potentially be rich in useful minerals. This region is also drained by a very dense hydrographic network whose waters would facilitate the transport of materials. The importance of alluvium is no longer to be demonstrated in terms of the quintessential mineral exploration site when indices are reported in a region. The case of Bétaré-Oya in the eastern Cameroon region can well illustrate it. There, many mining companies explore and exploit gold in placers, where one of which is just located below hills in Mali village. Numerous petro-structural and metallogenic studies have been conducted in the Lower Nyong region including Ngovayang, which has been strongly influenced by the eburnean orogeny. It appears that the Nyong unit, in general, contains relics of the TTG (Tonalite-trondhjemite-granodiorite) series, various intrusive rocks, and greenstone belts, all strongly affected by the eburnean orogeny around $2050 \mathrm{Ma}$, and intersected by dolerites [4] [5] [6]. In the same way, these results confirmed the presence of platinoids and minerals present on ultrabasic rocks. However, there is no real previous sedimentological study in the area. We have volunteered to start a study whose general objective is to know the sedimentological characteristics of the alluvium deposits of Lokoundjé River and its tributaries in the vicinity of Bipindi; deduce sediment deposition environment and associated sediment dynamism; identify relevant indicators that can reveal the origin of the minerals found; establish an evaluative draft of social and environmental impact in the context of a future alluvial mining operation. The expected results are to find mineralization indices in the area, which would be useful for mining exploration of gold and related minerals. 
Mining in the county is at an embryonic stage. Mining companies are currently exploring uranium, gold and iron in the area. In addition, sand quarries are exploited on the banks of the Lokoundjé River and on some of its tributaries Tyango and Nsola.

\section{Natural Environment and Geological Setting}

\subsection{Natural Environment}

The study area is located in the coastal plain region of Cameroon (Figure 1). The coastal plain is the lowest elevation zone $(0-350 \mathrm{~m})$, [1] [2] see in this plain a succession of three levels of increasing altitude from the sea to the southern plateau of Cameroon. However, the observation of the topographic map of Edea at the scale of 1:50,000 subdivide the study area into four geomorphological units where high altitudes represent the peaks of the Ngovayang mountain range (Figure 2). The climate of the zone is equatorial Guinean type with four seasons. The average minimal temperatures are in the region of $23.4^{\circ} \mathrm{C}$, with $32.5^{\circ} \mathrm{C}$ as monthly maxima [7]. The study area is dominated by evergreen forest with large buttressed and rooted trees (Figure 6) such as Microberlinia bisulcata and Piptadeniastrum africanum [8]. This forest is subject to strong anthropization. It is characterized by an abundance of rotang, raphial species; aquatic ferns and algae

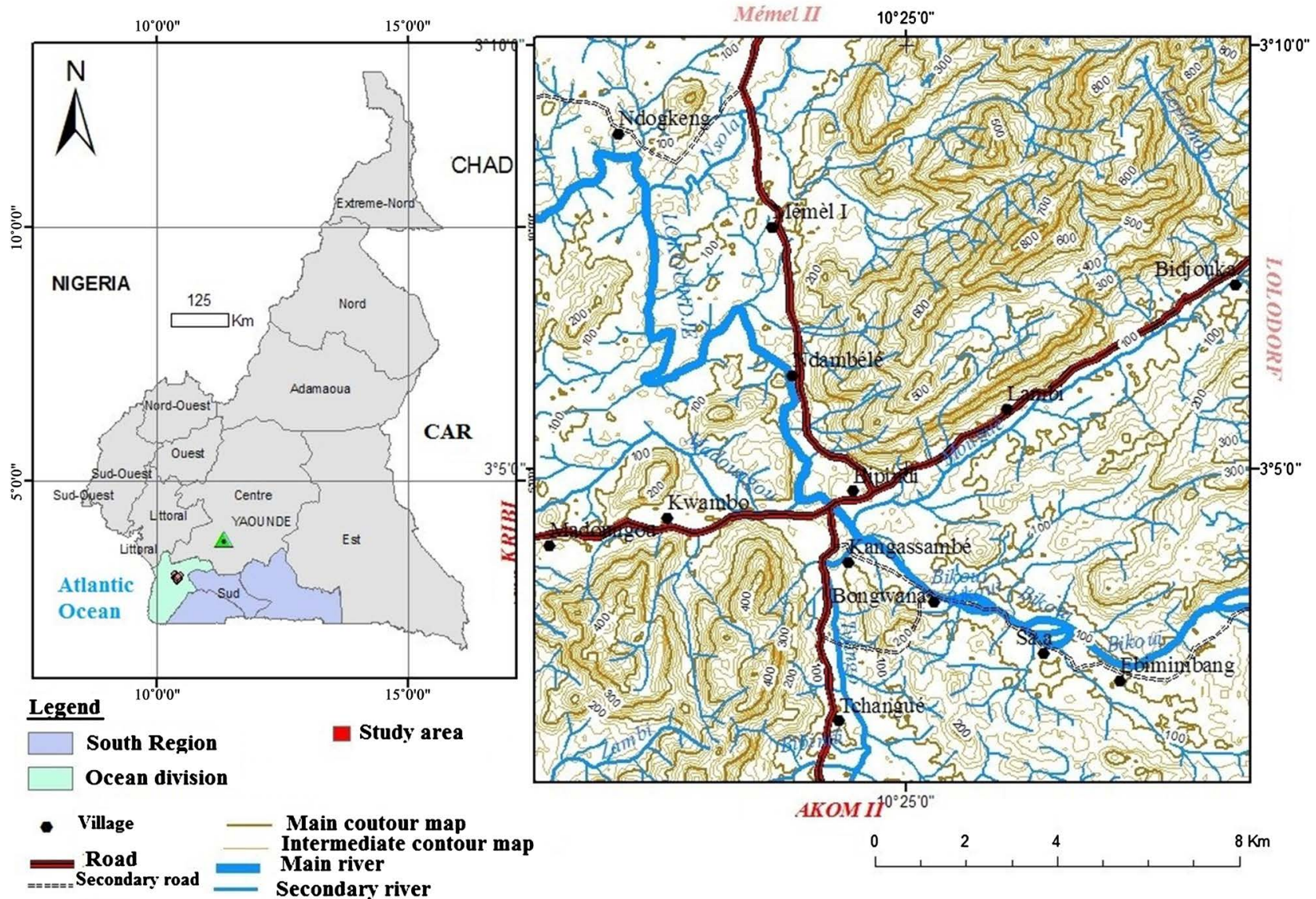

Figure 1. Location map of the Ngovayang area at Bipindi, southern Cameroon. 


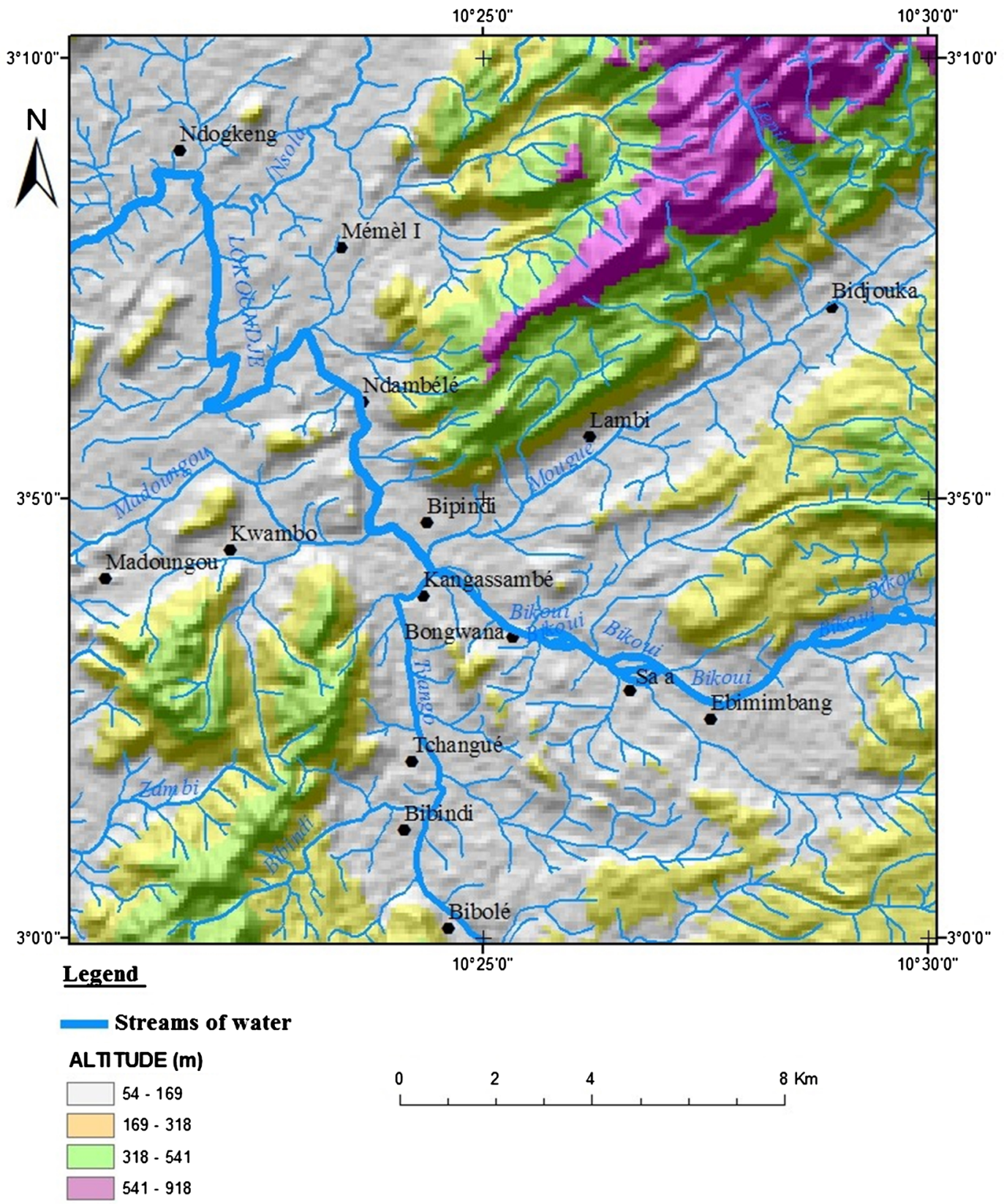

Figure 2. Geomorphological map of the study area extracted from the Edéa topographic map.

in marshy areas. Chinese bamboos are in hydromorphic soils. The hydrographic network of the study area is dense in lattices with a rectangular tendency. It is part of the Lokoundjé watershed, the main collector of the region. Its rivers are organized in a network of order four (Figure 4). Its watershed covers an area of $5200 \mathrm{~km}^{2}$ with a perimeter of $331.6 \mathrm{~km}$ [9]. The Lokoundjé River takes its source in the southern plateau of Cameroon and travels $216 \mathrm{~km}$ to the sea with a direction of flow ENE-WSW. In the same order, we find that all streams flow between fractures and are almost all affected by structural guidance. There are two main types of soils, based on the synthesis of soil studies in southern Cameroon [10] [11] [12] [13] [14]. We distinguish from this fact ferrallitic red and yellow soils 
on interfluves and hydromorphic soils in the lowlands.

\subsection{Geological Setting}

The complex is made up of three units namely: Ayina unit, Ntem Unit and the Nyong unit. The study area belongs to the lower Nyong unit of the Ntem group correspond to the remobilized northwestern border of the Congo Craton (CC) in southern Cameroon. The Lower Nyong unit consists of Archean and Paleoproterozoic rocks with tonalite-trondhjemite-granodiorite (TTG), dolerites, alkaline syenites, greenstone belts (epidotites, serpentinites), orthopyroxene-garnet gneisses (charnockites), garnet-amphibole-pyroxenites, biotite horn-blende gneisses, and BIFs [15] [16]. The region is affected by the eburnian orogeny 2 Ga years ago [4]. The Nyong Unit consists mostly of metasedimentary, meta-volcanic and intrusive rocks. Palaeoproterozoic rocks are ortho amphibolites (Figure 3), iron formations and intrusive granitoids alternating with various gneisses [17]. The zone underwent three deformations characterized by foliations, schistosities, folds, shears, recesses, joints, flanges, lineations and tension slits. According to the

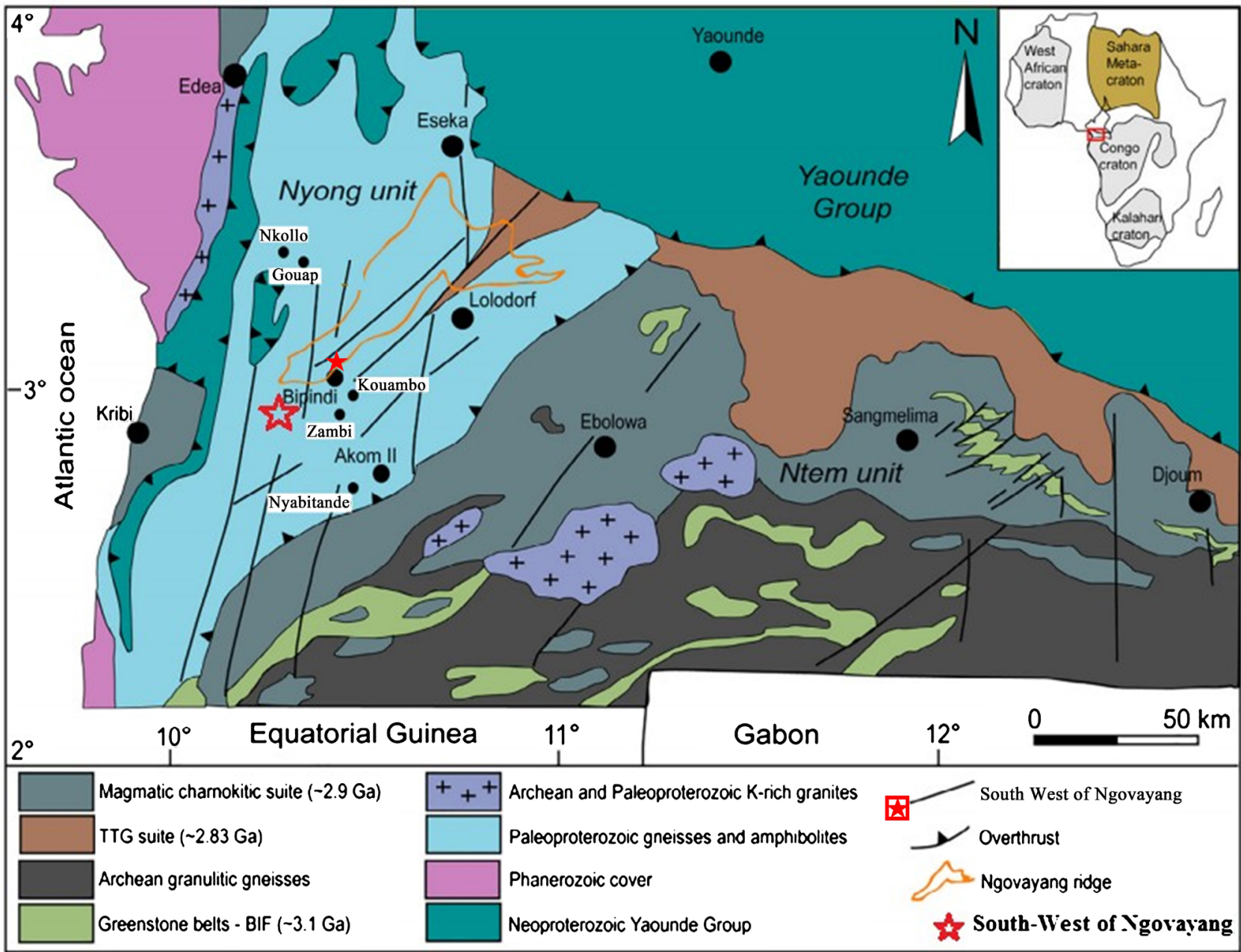

Figure 3. Geological map of SW Cameroon (modified after [17]) showing the Kpwa-Atog Boga area related to the Ngovayang massifs in [23]. 
work done by [17]-[22]. The dolerites, the peridotites and the gabbros are exposed in the form of veins intersecting the structure of the preceding rocks [5].

The study area is composed of the rocks from the greenstone belt. Firstly they are Ortho and para-metamorphic rocks that are generally leucocratic gneisses, amphibolic gneisses and calcium gneisses (Figure 3). They are generally in the form of balls on firm ground and in slabs at the level of the rivers or in banks near. Secondly they are Magmatic rocks that are generally syenites, pyroxeno-amphibolites, iron formations and basic and ultrabasic rock veins. It shows that, the Lower Nyong unit has been altered during geological time because of numerous climatic changes on the one hand, and on the other hand this alteration is favored by the nature of the rocks called ultrabasics and their tectono-metamorphic evolution. Ultrabasics are rocks that rapidly deteriorate because of their high percentage of ferromagnesis, hence an interest for mining exploration in recent sedimentary deposits.

\section{Methodology}

The methodology of work is divided into two major activities including field campaigns and laboratory work. The fieldwork consists of recognition and delimitation of the sector to be studied using map 1/200,000 of Edéa NA-32-XXIII; the choice of sampling sites (Figure 4) and their geographical location (Table 1). Sample collection was done in holes. Their depth varies from one to one and a half meters, depending on the appearance of water (Figure 5, Figure 6). Where, we collected one to three samples per hole from the base upwards. In laboratory, sand samples are subjected to sedimentological analyzes namely the granulometry, morphoscopy of quartz grains, the study of heavy minerals and the morphometry of pebbles.

The granulometric technique makes possible to establish a precise textural description of the sediment and to understand the active mechanisms during the transport and the deposition of the particles. The samples, after drying in an oven at $108^{\circ} \mathrm{C}$ for 24 hours, are subjected to successive quartering until $200 \mathrm{~g}$ of material are obtained in each sample. Then the $200 \mathrm{~g}$ are tap washed in a $50 \mathrm{mi}-$ cron sieve to remove fine particles, then dried and weighed. At the end the sediment is passed through a sieve column arranged in a decreasing manner (2 $1.60-0.800-0.315-0.250-0.200-0.160-0.125-0.080-0.063-0.050-<0.050$ $(\mathrm{mm}))$. The goal here is to determine the percentage of refusal on each sieve and weigh it.

$$
M i=(M R \times 100) / M R C ;
$$

Mi: Relative frequency of the particles, MR: Refusal mass, MRC: Total mass of cumulated refusals.

Concerning the morphoscopy, on the mesh samples of: $1.250-0.800 \mathrm{~mm} ; 0.8$ - $0.315 \mathrm{~mm}$ and $0.315-0.200 \mathrm{mn}$, we randomly take and count 100 grains of quartz per sample for the observation by binocular magnifying glass to inspect the state of the surface, the shape of the quartz grains per sample. It consists in 


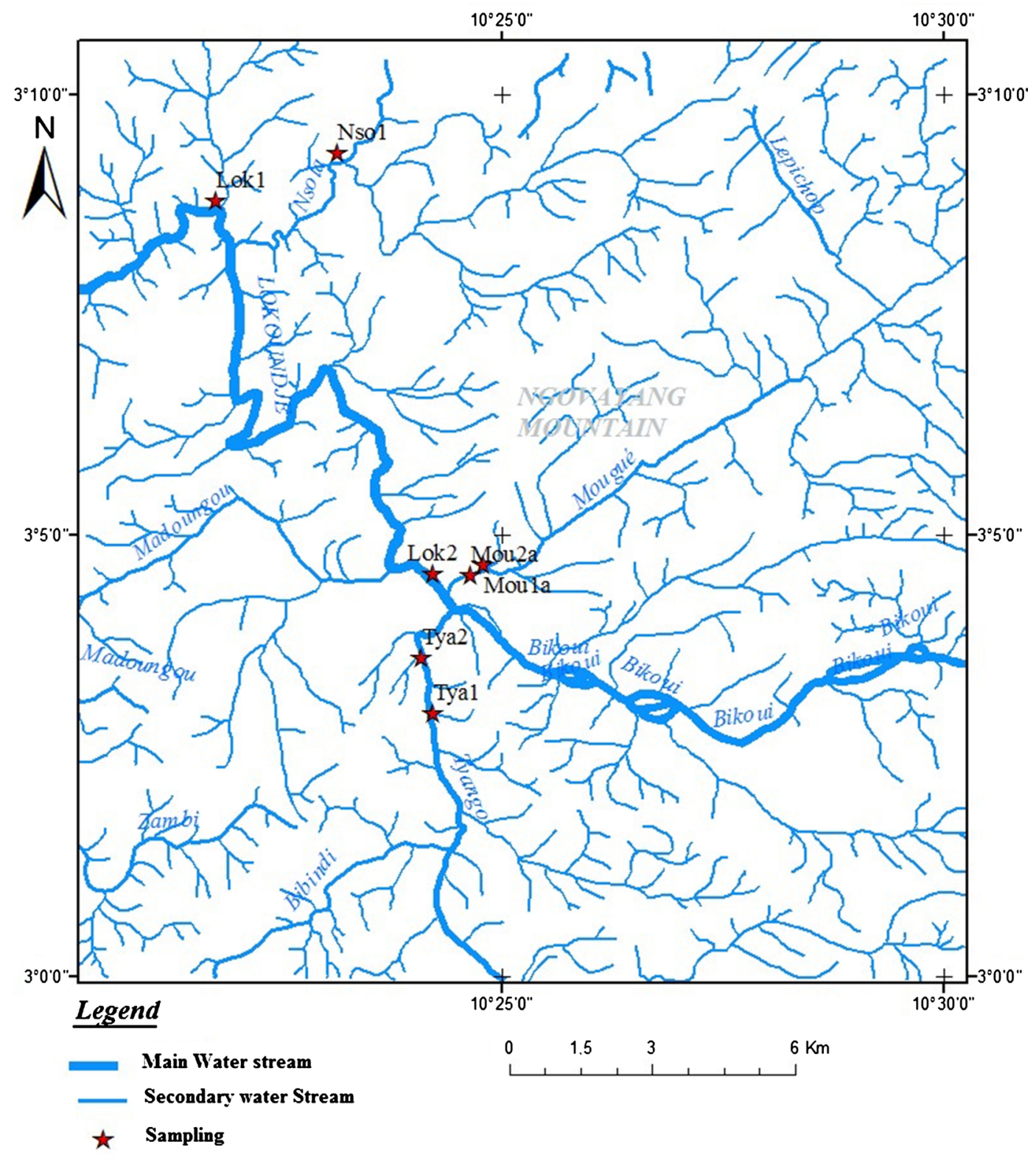

Figure 4. Sampling points map and Hydrographic map of the study area extracted from topographic map $2 \mathrm{~A}$ at $1 / 50,000$.

Table 1. Geographical coordinates of sampling sites.

\begin{tabular}{|c|c|c|c|c|}
\hline Sites & Latitude & Longitude & Altitude (asl) & Sampling \\
\hline Lokoundjé 1 & N030'ㄴㄷㄴ & $\mathrm{E} 010^{\circ} 21^{\prime} 46.2^{\prime \prime}$ & $52 \mathrm{~m}$ & $\operatorname{Lok}_{\mathrm{a}}, \operatorname{Lok}_{\mathrm{b}} ; \operatorname{Lok}_{\mathrm{c}}$ \\
\hline Lokoundjé 2 & N03 $04^{\prime} 32.5^{\prime \prime}$ & $\mathrm{E} 010^{\circ} 24^{\prime} 11.6^{\prime \prime}$ & $56 \mathrm{~m}$ & Lok $2_{\mathrm{a}}$; Lok $2 \mathrm{~b}$, Lok $2_{\mathrm{c}}$ \\
\hline Mougué 1 & N03 $04^{\prime} 38.2^{\prime \prime}$ & E010²4'47.3" & $57 \mathrm{~m}$ & Mou 1 \\
\hline Mougué 2 & N03 ${ }^{\circ} 04^{\prime} 34^{\prime \prime}$ & E010² $24^{\prime} 37.5^{\prime \prime}$ & $56 \mathrm{~m}$ & Mou 2 \\
\hline Nsola & N0301'20.3" & E010²3'7.4" & $60 \mathrm{~m}$ & Nso $_{a}$, Nso $_{b}$, Nso $_{c}$ \\
\hline Tyango 1 & N0302'59.1" & $\mathrm{E} 010^{\circ} 24^{\prime} 12.2^{\prime \prime}$ & $54 \mathrm{~m}$ & Tya $_{a}$, Tya $_{b}$, Tya $_{c}$ \\
\hline Tyango 2 & 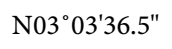 & $\mathrm{E} 010^{\circ} 24^{\prime} 04.9^{\prime \prime}$ & $54 \mathrm{~m}$ & Tya $2_{a}$, Tya $_{b}$, Tya $2_{c}$ \\
\hline
\end{tabular}




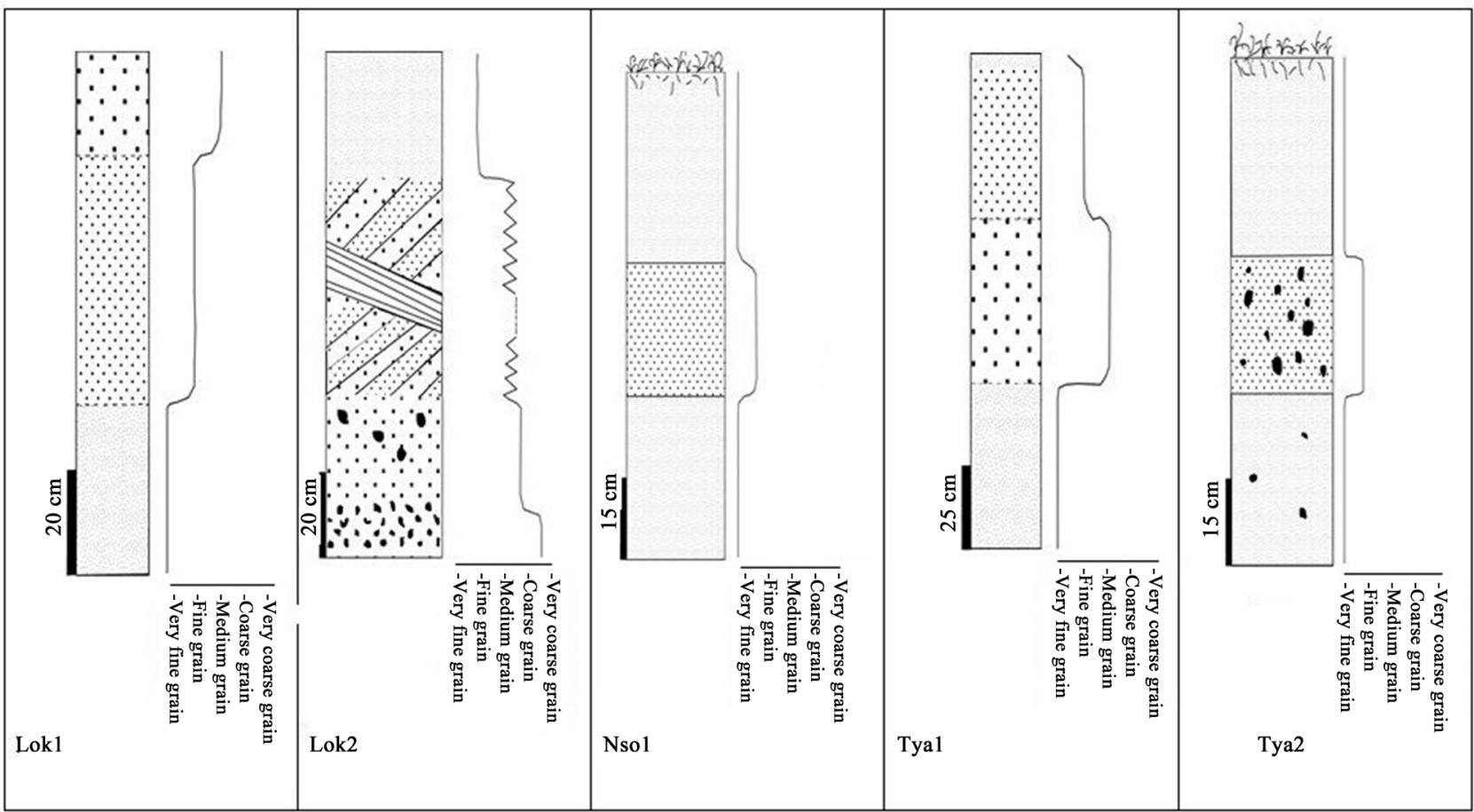

Figure 5. Plate log of different holes samples collection.
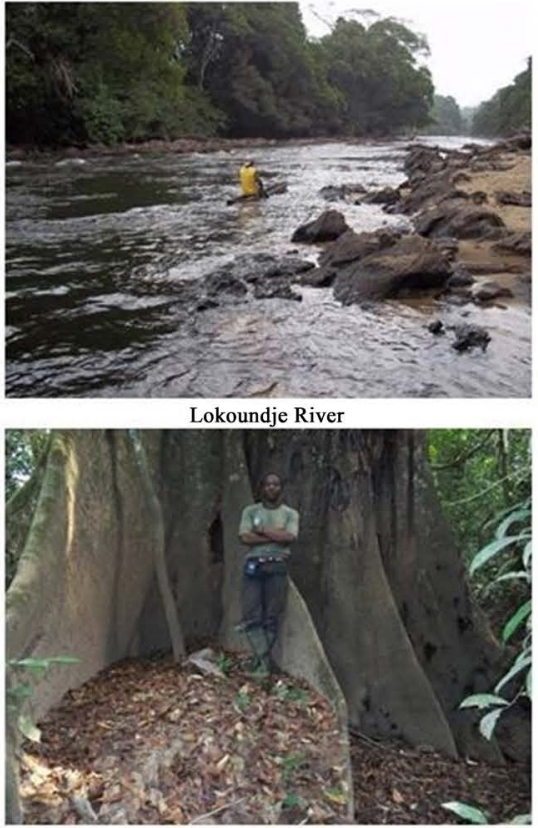

Counterforced trees
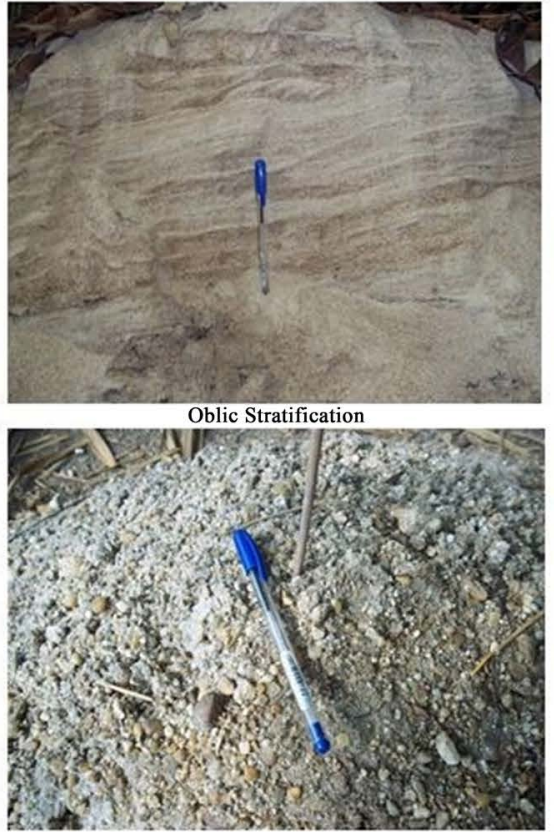

Tyango2 Pebbles

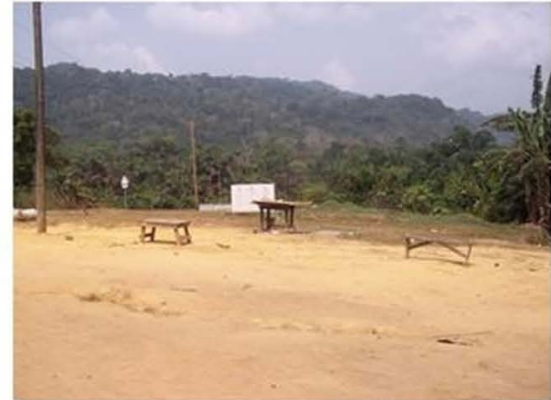

View of Ngovayang Mountain

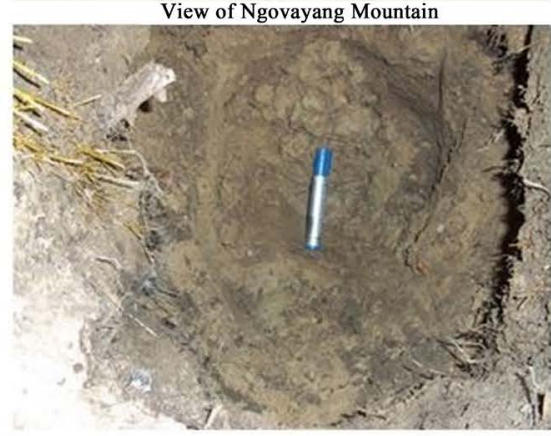

Sampling in Lokoundjél

Figure 6. Plate of some field pictures.

determining the mode and the duration of transport of the grains, thus making it possible to reconstruct the geological history of the latter.

Heavy minerals are minerals with a density greater than 2.89 . Their study consists in knowing the nature of the rock they come from on the one hand and on the other hand to specify their distributing province. Preparation techniques 
are those recommended by [24] [25].

Pebbles for morphometry study are aggregates used to apprehend transport agents and to evaluate the wear process of these materials. This indicates that the forms observed depend simultaneously on the hardness of the original materials, as well as the mode and duration of transport [26]. According to [27] it is necessary to take 50 pebbles and examine each of them using a caliper (Figure 7).

Calculate from this fact:

The flattening index $\mathbf{A}=\mathrm{L}+1 / 2 . e$;

The blunt index I = 2r.l. 1000/L;

The dissymmetry index $\mathrm{D}=1000$. AC/L.

\section{Results}

\subsection{Granulometry}

The histograms relate to Wentworth's classification of the diameters (d) of the sand grains. We obtained sixteen (16) histograms of which four are represented here (Figure 8).

The histograms of the 16 samples presented two modes respectively in classes $0.800 \mathrm{~mm}-0.315 \mathrm{~mm}$ and $0.200 \mathrm{~mm}-0.160 \mathrm{~mm}$; with the exception of the histograms of samples Moula and Nso1a. The major parts of the dominant particles have a diameter between $0.315 \mathrm{~mm}-0.080 \mathrm{~mm}$.

\section{Cumulative curves}

In the same way as for histograms, we plotted on the abscissa the diameters of the meshes on a logarithmic scale and on the ordinate the cumulative percentages in mass of rejections expressed on an arithmetic scale. In order to have reliable results of the sediment deposition mode, the coarsest ones that are deposited first, and ends after [28]. Retrograde accumulation is used to show coarsest

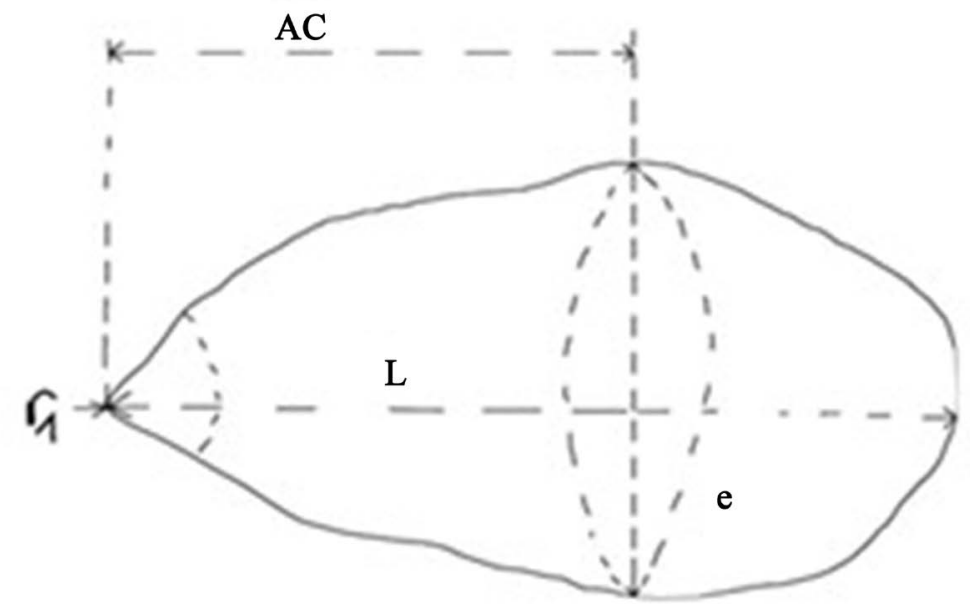

Figure 7. Morphometry of a pebble (modified after [27]). 

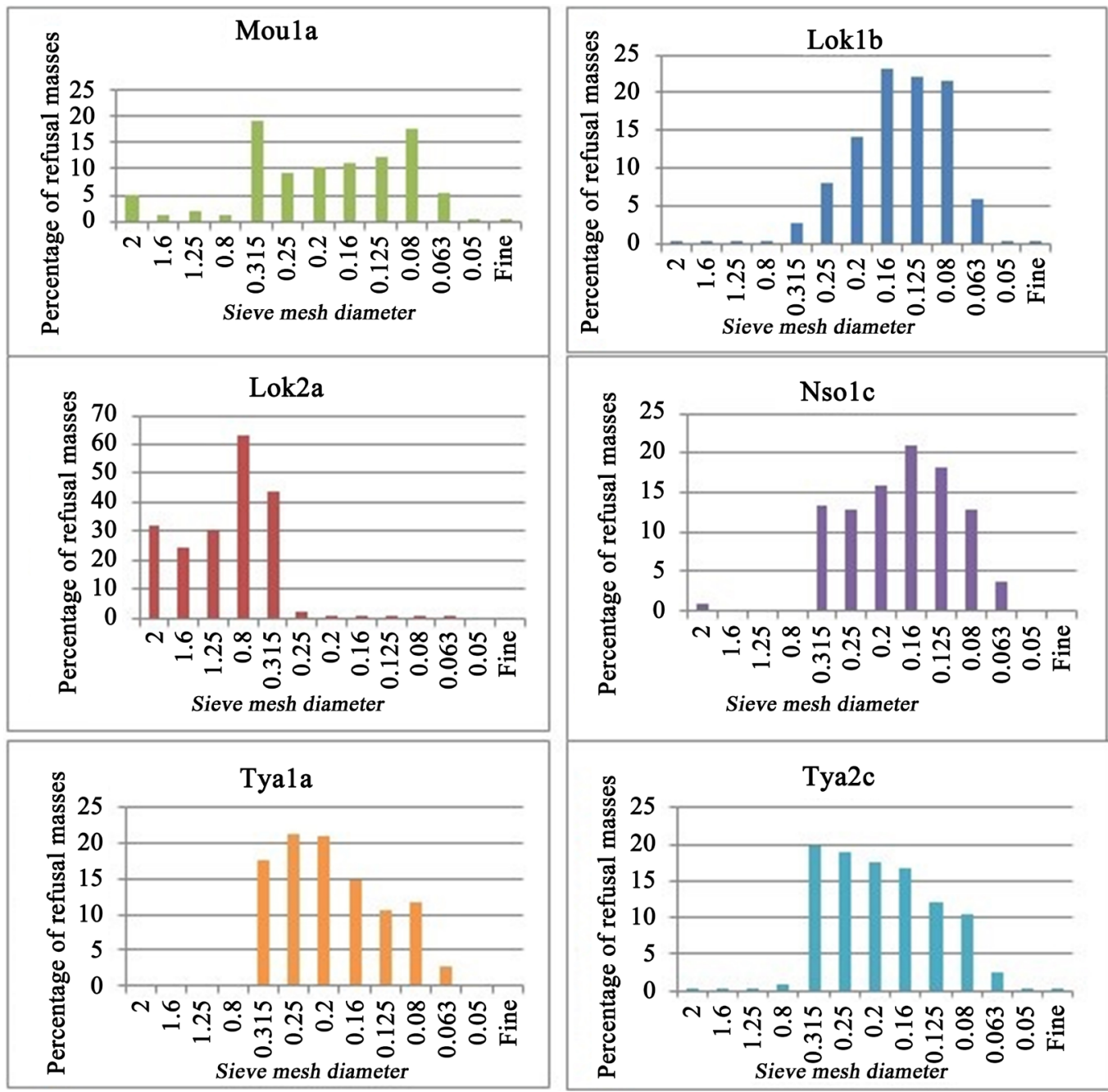

Figure 8. Histograms from the different sites of samples.

elements to the finest elements. The quartiles defined for this purpose are used to determine the granulometric parameters such as the Krumbein Qdphi or quartile of deviation. It is a ranking index that allows assessing the extent of sorting actions during transport and sediment deposition. It also makes it possible to determine whether the sediment is better sorted, especially as its value will approach zero.

$$
\mathrm{Qdphi}=(\mathrm{Q} 1 \times \mathrm{Q} 3) / 2
$$

Qdphi: Quartile of deviation.

The Sorting Index $(\mathrm{S} 0=(\mathrm{Q} 1 / \mathrm{Q} 3) 1 / 2)$ is an index whose limits are proposed by [29], and which gives information on the type of filing classification. The consequences are as follows:

S0 $<1.23$; very high grade (sediment very well classified);

$1.23<\mathrm{SO}<1.41$; good grade (well classified);

$1.41<\mathrm{S} 0<1.74$; medium grade (averagely classified);

$1.74<\mathrm{S} 0<2.00$; poor classification (poorly classified);

S0 $>2.00$ : very poor grade. 


\section{Coefficient of Asymmetry}

Asymmetry provides more information on the depositional environment than transport conditions [26]. It expresses the distribution of the elements with respect to the median Q2, and is expressed according to the formula:

$$
\mathrm{A}=(\mathrm{Q} 1 \times \mathrm{Q} 3) / \mathrm{Q} 22
$$

The limits of this coefficient imply the following consequences.

$\mathrm{A}<1$ : Classification is done on the side of coarse elements. Asymmetry is said to be negative and results in the elimination of the finest fractions either by high turbidity, it is most often torrential.

A $>1$ : The classification is made towards the finer elements, the asymmetry is said to be positive. These are deposits characterizing the basin bottoms.

$\mathrm{A}=1$ : The mode of the curve coincides with the median or average diameter (these are sediments called little evolved.

The results of the various calculations of the sedimentological indices (Qdphi, S0, As) are recorded in the table (Table 2).

The curves of the cumulative percentages of the samples show a fairly steep slope. The granulometric parameters are generally those of very well classified sediment, very well sorted and of negative asymmetry. In this assumption from granulometric study, the majority of histograms show a unimodal particle size appearance. This indicates that there is a single source of sediment. Moreover, the observed bimodality in Moula and Nsolb samples suggests that the sediments are derived from more than one source. The deposit methods are formed

Table 2. Summary of the various granulometric parameters calculated.

\begin{tabular}{ccccccc}
\hline Sample & Q1 $(\mathrm{mm})$ & Q2 $(\mathrm{mm})$ & Q3 $(\mathrm{mm})$ & Qdphi & $\mathrm{A}$ & $\mathrm{S}_{0}$ \\
\hline Lok1a & 0.13 & 0.18 & 0.24 & 0.016 & 0.963 & 1.36 \\
Lok1b & 0.15 & 0.15 & 0.23 & 0.017 & 1.553 & 0.34 \\
Lok1c & 0.16 & 1.80 & 0.21 & 0.017 & 0.010 & 1.14 \\
Lok2a & 0.85 & 1.10 & 1.80 & 0.76 & 1.264 & 1.45 \\
Lok2b & 0.70 & 1.00 & 1.35 & 0.47 & 0.945 & 1.39 \\
Lok2c & 0.33 & 0.45 & 0.60 & 0.099 & 0.977 & 1.35 \\
Mou1a & 0.128 & 0.21 & 0.47 & 0.030 & 1.364 & 1.91 \\
Mou2a & 0.130 & 0.18 & 0.22 & 0.014 & 0.883 & 1.30 \\
Nso1a & 0.20 & 0.34 & 0.57 & 0.057 & 0.986 & 1.69 \\
Nso1b & 0.140 & 0.195 & 0.185 & 0.013 & 0.681 & 1.15 \\
Nso1c & 0.145 & 0.190 & 0.170 & 0.012 & 0.683 & 1.08 \\
Tya1a & 0.37 & 0.46 & 0.60 & 0.111 & 1.049 & 1.27 \\
Tya1c & 0.185 & 0.218 & 0.272 & 0.025 & 1.059 & 1.21 \\
Tya2a & 0.267 & 0.40 & 0.76 & 0.101 & 1.268 & 1.69 \\
Tya2b & 0.261 & 0.43 & 0.71 & 0.092 & 1.002 & 1.65 \\
Tya2c & 0.182 & 0.22 & 0.282 & 0.025 & 1.060 & 1.244 \\
\hline & & & & & &
\end{tabular}


by traction, saltation and suspension (Figure 9).

\subsection{Morphoscopy}

The grains observed are classified into several types: the unworn, the blunted shape and the glowing sub-blunt shape. The different results obtained following observations of quartz grain surfaces with a binocular magnifying glass are shown as follows (Table 3 ).

The morphoscopy shows that the grains have more than $80 \%$ at an angular
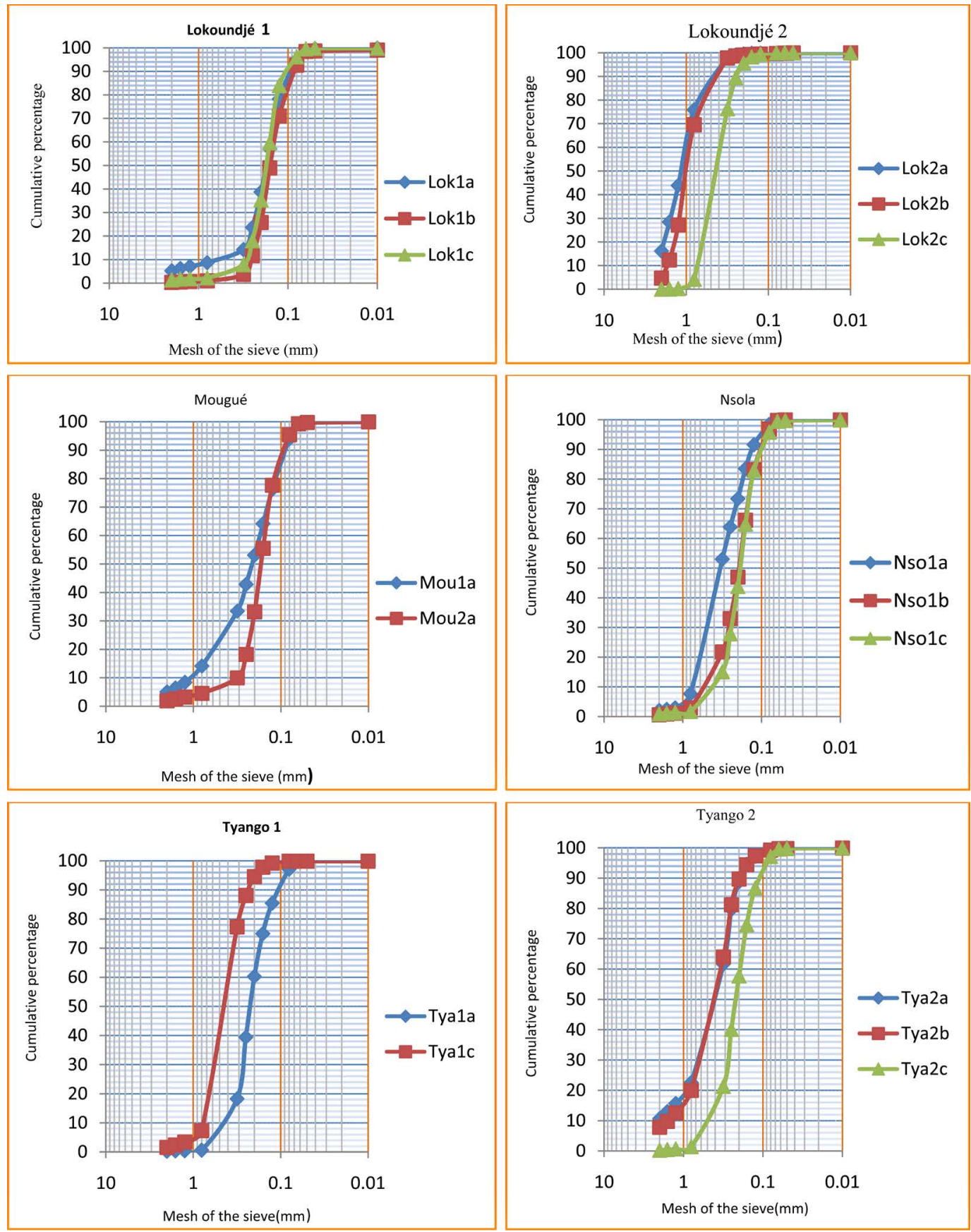

Figure 9. Cumulative curves showing well sorted and classified sand grain at all the sites. 
Table 3. Counting results of the surface aspects of quartz grains and their average percentage.

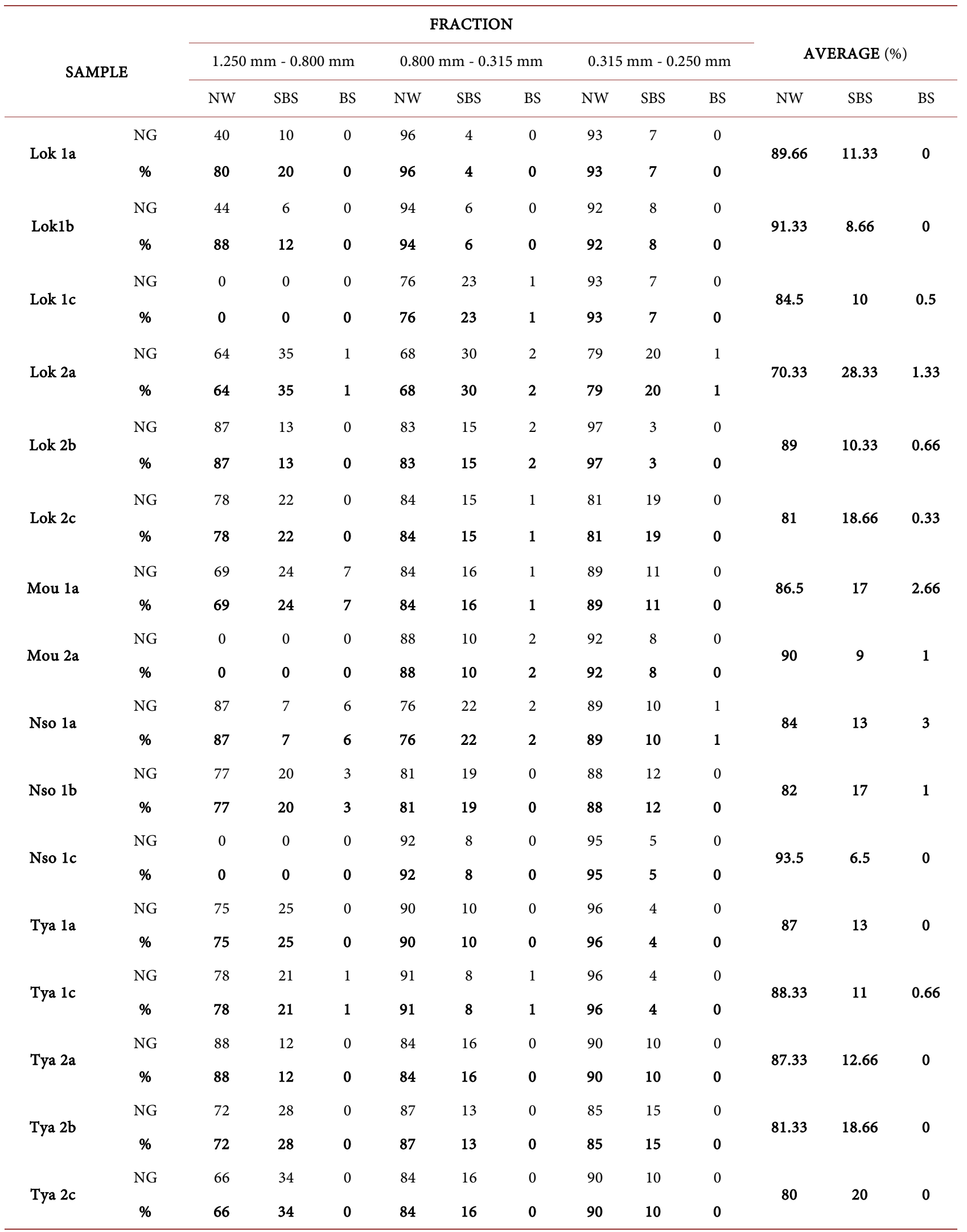

NG: Number of quartz grain, NW: Non Worn, SBS: Sub Blunt and Shiny, BS: Blunt and Shiny. 
appearance (Figure 10). Dirty or yellowish color is observed in some grains but in a negligible volume. It is the successful outcome of the presence of iron oxides. Lokoundjé the main collector with a length of $216 \mathrm{~km}$ cannot quite polish the surface of the sand grains as the necessary distance is approximately $300 \mathrm{~km}$. $\mathrm{S}_{\mathrm{o}}$ the source of sediment is more or less proximal. This is somehow evidence of a fluvial environment where the grain of sand from tributaries and hazards suffered by the Lokoundjé. This hypothesis is supported by the presence of metal oxides that permeate or cover some sand grains. This is evidence of weathering in forested areas, where sediments are not easily transported in the calm waters. The second category consists of sub-rounded grains. It represents $19 \%$ of the grains of sand. These are major part of medium to coarse sands. Grains have shapes or contours bad cut. Some grains, like angular present piecemeal metal film reddish color. We can say that these grains are from a more or less distal source and are subject to fluvial transport. The third category is worn grain, it is the least represented. Moreover, these grains could come from a more or less distal source, but in flood conditions where grains would clash and wear out. The presence of non-round grains mats indicates the absence of a wind transport can be explained by the thick forest cover in the region. In view of this, we will remember that the presence of angular grains is more influent than the Lokoundjé. However, sub-rounded covered with a deposit of fluvial environment or deposit river low energy. The absence of the mat round type characterizes

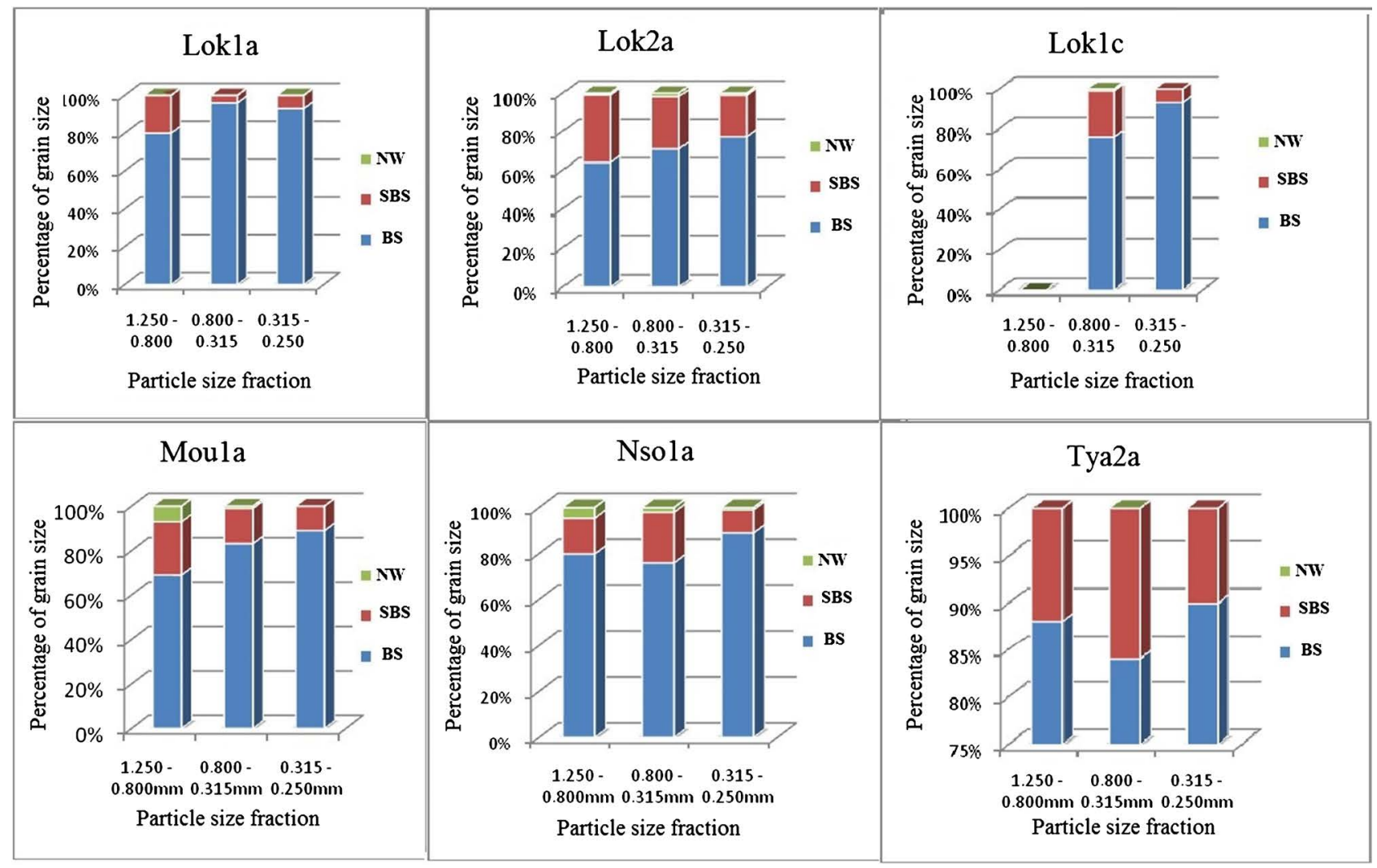

Figure 10. Some Morphoscopic histograms. 
fluvial transport forest.

\subsection{Heavy Minerals}

Heavy minerals are minerals with a higher density than bromoform (2.89). These are most often ferromagnesian minerals, metamorphic silicates, titaniferous minerals and accessories. They are most often said to be economical and profitable or interesting.

In the study there is a high content of zircon (Figure 11) and garnet. The other minerals are on the order of two to three percent on average (Table 4). In addition we have enough of opaque oxides which are most often iron minerals, that is to say more than $50 \%$ of the total volume of minerals.

\section{Garnet and mafic}

Garnet is abundant. It is colorless in natural light and off in polarized light. He cracked the terrain very strong, with inclusions of quartz. It is a mineral of general metamorphism of low to medium pressure and medium temperature. Its average content is estimated at about $13 \%$. The green hornblende is observed in samples Moula, Tyalb. It occurs as short fragments or lying prism. The green to
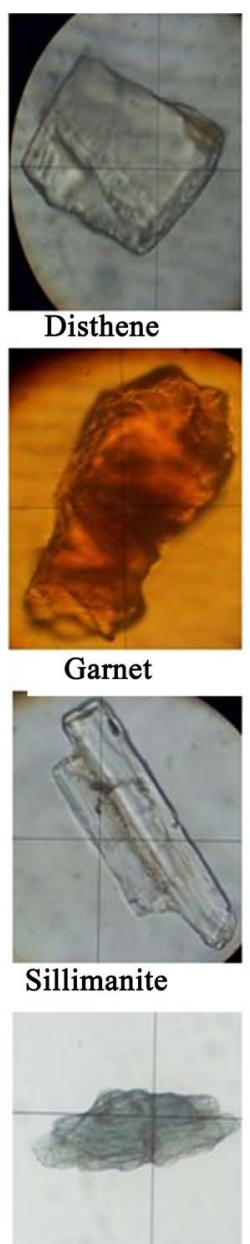

Hornblend

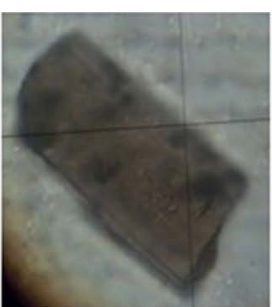

Tourmaline

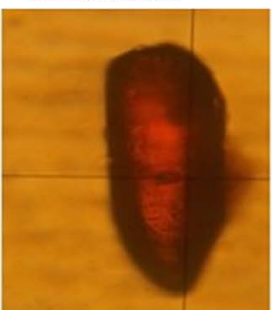

Zircon

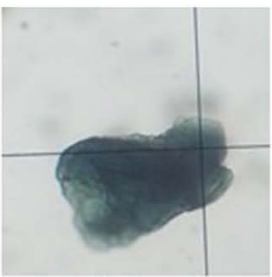

Epidote
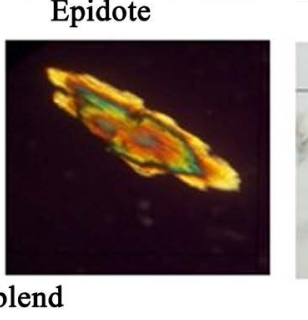

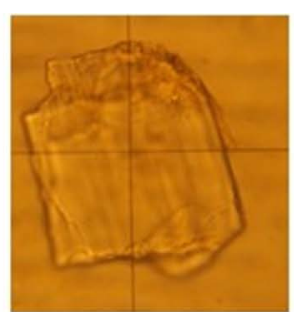

Zoisite

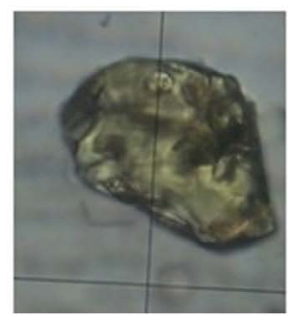

Monazite

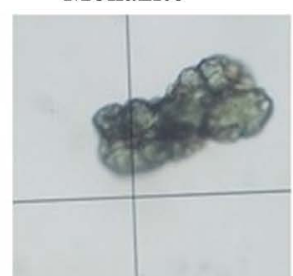

Andalusite

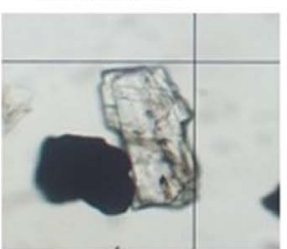

Hornblend

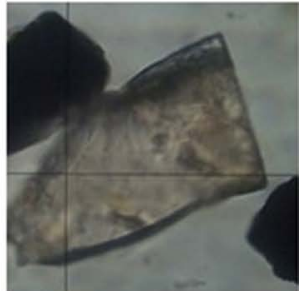

Topaze

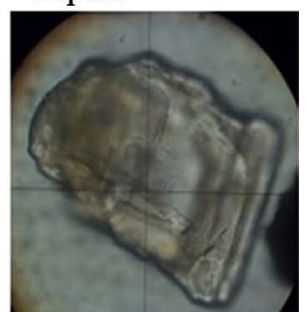

Diopside

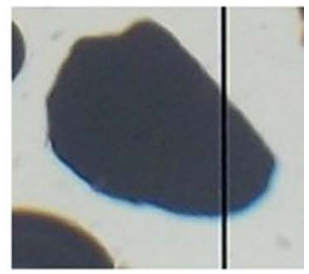

Oxides

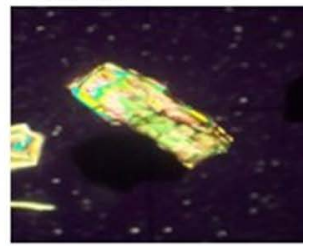

Figure 11. Plate showing heavy minerals from sands (Optical microscope). 
Table 4. Inventory of heavy minerals in the presence.

\begin{tabular}{|c|c|c|c|c|c|c|c|c|}
\hline SAMPLES & $\begin{array}{c}\text { Lok1b } \\
0.200-0.160\end{array}$ & $\begin{array}{c}\text { Lok1b } \\
0.125-0.080\end{array}$ & $\begin{array}{c}\text { Moula } \\
0.200-0.0160\end{array}$ & $\begin{array}{c}\text { Moula } \\
0.125-0.080\end{array}$ & $\begin{array}{c}\text { Nsola } \\
0.200-0.160\end{array}$ & $\begin{array}{c}\text { Nsola } \\
0.125-0.080\end{array}$ & $\begin{array}{c}\text { Tya1a } \\
0.200-0.160\end{array}$ & $\begin{array}{c}\text { Tyala } \\
0.125-0.080\end{array}$ \\
\hline \multicolumn{9}{|l|}{ MINERALS } \\
\hline Andalusite & - & - & 2 & - & - & 2 & - & 2 \\
\hline Apatite & - & - & - & - & - & - & - & 2 \\
\hline Biotite & - & - & - & - & - & 4 & - & - \\
\hline Diopside & - & - & 6 & - & 2 & - & - & - \\
\hline Disthene & 6 & - & - & 2 & - & - & 2 & - \\
\hline Epidote & 14 & 12 & 14 & 12 & 10 & 10 & 20 & 12 \\
\hline Garnet & 16 & 13 & 16 & 8 & 18 & 8 & 14 & 20 \\
\hline Green Hornblende & 8 & - & 2 & 2 & 6 & - & 5 & 6 \\
\hline Brown Hornblende & - & - & - & 2 & - & - & - & - \\
\hline Monazite & - & 5 & - & 0 & - & - & - & - \\
\hline Oxydes & 30 & 46 & 38 & 48 & 42 & 60 & 26 & 32 \\
\hline Sillimanite & 6 & - & - & - & 4 & 2 & 4 & 2 \\
\hline Sphene & - & - & - & 2 & 4 & - & - & - \\
\hline Topaze & - & 2 & 2 & 2 & - & - & - & - \\
\hline Tourmaline & - & 2 & 3 & 4 & - & 2 & 2 & 2 \\
\hline Zircon & 12 & 18 & 12 & 16 & 8 & 6 & 16 & 18 \\
\hline Zoisite & 8 & 2 & 5 & 2 & 6 & 6 & 4 & 6 \\
\hline TOTAL & & & & 100 & & & & \\
\hline
\end{tabular}

dark green NAPL, it also has shades of the second order. Its pleochroism is visible with oblique extinction. It represents less than $5 \%$ in these samples. The tourmaline is found in all samples prismatic. It is yellowish in color and light yellow in NAPL LPA. Its relief is moderate and represents $2 \%$. The biotite is observed only in the sample Nsolb, yellowish to reddish brown in polarized light. It is being chlorite and is estimated at about $2 \%$.

\section{Silicates metamorphism}

They are formed under conditions of medium to high pressure and medium temperature. The andalusite is rare, and is found in Moulb and Tya samples. It is colorless to pale pink, medium terrain. Comes in the form of angular grains, it polarizes in vivid hues of the second order and represents about $1 \%$ in these samples. The kyanite is observed in samples Tyalb Moulb and it is colorless NAPL blue to pale blue LPA. It is usually in the form of elongated tablets. Its divisions are orthogonal and an estimated $2 \%$ content. Sillimanite occurs with prism-shaped serrations or fibers. It is found in most of the concentrates. It is colorless and clear in strong relief. The Sillimanite polarized in purplish red hues of the first order and represents an average of $3 \%$. 


\section{Titaniferous minerals}

The Sphene is present in Moulb and Nsolb samples. It is colorless and greenish blue in natural light LPA. Its terrain is very uncommon with pleochroism. It has an oblique extinction in polarized gray tint of the first order, it is highly birefringent, and its content is estimated at $2 \%$.

\section{The accessory minerals}

Apatite is present in the sample Tyala, colorless to light polarized dark gray PCPA its extinction is right. Monazite is present in the sample Lok1; it has a yellowish brown to orange-green. It is split and has a shiny glaze. We estimate that less than one percent of the volume of the rock. The topaz is also estimated at less than one percent. It has a prismatic colorless color tone blue with a glassy appearance NAPL. We watched in Lok1 and Soft samples.

\section{Opaque oxides}

Opaque oxides are present in all samples collected sites. They represent on average $40 \%$ of the sample volume of thin sections. They come in different shapes and are visible only in polarized light (Figure 11). In sum, the study shows that the source of sediment is of magmatic and metamorphic origin respectively with minerals such as hornblende, zircon, tourmaline and other minerals such as kyanite and sillimanite.

\subsection{Morphometrical Study of Pebbles}

The study concerns pebbles essentially collected in the Tyango's tributary alluvium. The alluviums of the other tributaries including those of Lokoundjé River do not have pebbles. The results obtained after studies are also recorded in the table below.

The informations collected on studies of pebble Tyango River (Table 5) indicate that the flattening index, show unimodal curves. So, shows that the source is unique, pebbles are relatively flat and more than $50 \%$ have sub-spherical shape.

Table 5. Distribution of different morphometric index measurements of pebbles.

\begin{tabular}{|c|c|c|c|c|c|c|}
\hline \multicolumn{7}{|l|}{ Flattening } \\
\hline Class & \multicolumn{2}{|r|}{$100-200$} & $200-300$ & $300-400$ & \multicolumn{2}{|c|}{$400<$} \\
\hline Effective & \multicolumn{2}{|r|}{15} & 15 & 8 & \multicolumn{2}{|c|}{2} \\
\hline Rate & \multicolumn{2}{|r|}{$2 \%$} & $30 \%$ & $16 \%$ & \multicolumn{2}{|c|}{4} \\
\hline \multicolumn{7}{|c|}{ Assymetrical } \\
\hline Class & & $<400$ & $400-500$ & $500-600$ & $600-700$ & $700<$ \\
\hline Effective & & 4 & 9 & 19 & 14 & 4 \\
\hline Rate & & $18 \%$ & $18 \%$ & $38 \%$ & $28 \%$ & $8 \%$ \\
\hline \multicolumn{7}{|l|}{ Blunt } \\
\hline Class & $<100$ & $100-200$ & & $300-400$ & $400-500$ & $500<$ \\
\hline Effective & 1 & 14 & 18 & 9 & 3 & 5 \\
\hline Rate & $2 \%$ & $28 \%$ & $36 \%$ & $18 \%$ & $6 \%$ & $10 \%$ \\
\hline
\end{tabular}


The blunt index gives information on the situation of the source. In this case, the shape of the curve is bimodal and is sub-blunt roller. This is evidence of a more or less short transportation. The Assymetrical index gives evidence that the pebbles are different from a sphere, because nearly $80 \%$ of pebbles collected exhibit disphérique form. We may retain in light of all this information, the rollers of the river are Tyango proximal origin have undergone short transportation. They are slightly worn and disphériques.

\section{Discussion}

\subsection{Depositional Set up}

Bipindi area is dominated by the southwestern tip of the Ngovayang, altitude of $1090 \mathrm{~m}$. It is a vast plain that extends to the Atlantic Ocean which is located at about $70 \mathrm{~km}$. This potentially mining area is subject to an Equatorial Guinean climate. Significant rainfall promotes the erosion of materials, which are kidding from the hillsides of Ngovayang Mountain to Lokoundjé River and its tributaries located below. The dip of approximately $5^{\circ}$ to the west of oblique stratifications indicates that the deposits describe a monoclinal structure where an accumulation of continental and meteoric iron occurs. This is all the more confirmed by the unstirred place, with the result of a good grading and sorting of grains.

With respect to the deposit environment of alluvial, geodynamic reveals many variations on rock types. Moreover, they are the consequence of the variations of the conditions of the environment. The sands in the course of the study are fine and coarse as well. We stipulate that this is a result of hot period, while keeping in mind that it is in fluvial channels where there are many leaching elements. Nevertheless, we can use the color and thickness criteria of the facies to better decipher the depositional periods. Thus the small oblique stratification corresponds to the periods of flooding, whereas the thick stratifications correspond to the periods of low water.

\subsection{Mining Interest}

In view of all studies carried out including the geomorphology aspect of the environment, we do believe that the southwestern sector of the Ngovayang-Eséka range in Bipindi has the characteristics of a beneficial minerals accumulation. Then by taking into account the age of the materials, the alluvial deposits are all repositories. However, at the regional scale, the majority of fluvial placers date from Cenozoic [30] [31]; this is the case in the area with Precambrian basement rocks, Eburnean age.

According the tonnage and the content, the information obtained from the work on the site of panning of Jules Amenguelé in Abiété Yenjok located to about thirty kilometers in the south. The result content show: $0.35 \mathrm{~g} / \mathrm{m}^{3}$ and 1.22 $\mathrm{g} / \mathrm{m}^{3} \mathrm{Au}$. According to [32] the high tonnage is 0.1 to $100 \mathrm{Mt}$ with low levels from 0.05 to $0.25 \mathrm{~g} / \mathrm{T} \mathrm{Au}$ and $50-200 \mathrm{~g} / \mathrm{T}$ in $\mathrm{Sn}$. Moreover, a minimum level for a profitable operation is $0.1 \mathrm{~g} / \mathrm{m}^{3}$ [33]; which is far below the levels observed in 
our region. In addition, in the observation of heavy minerals, we have more than $50 \%$ opaque oxides which are relevant indicators for the presence of useful minerals, as it is the case with placers elsewhere. These minerals are the following: Diamond, platinum, zircon, sapphire, tin, titanium, chromite and many others. In addition, sedimentological studies confirm a short transport of sediments that is unfavorable to the dilution of particles with mechanical transport by water. Thus, the useful minerals at best will be found in their primary form. This idea is supported by the discovery one year ago, of gold in alluvial deposits upstream, in the north of the Ngovayang-Eseka range. Currently this is subject to exploitation by mining artisans in the town of Eseka.

In short, economic ores are concentrated by gravity, chemically resistant to weathering and durable. They include zircon, rutile, monazite and many others in the surrounding sediments during a long period. Thus the recent deposits are found in basin context, either in surface and sub-surface environments [33] where they can be influenced by climatic hazards and biological organisms. We retain that the Ngovayang-Eséka range, in a collisional context between the South Cameroon Plateau and the Congo's north Equatorial Craton, is the major provider of useful sediments and concentrations in our area; further investigations should be done to accurately evaluate the tonnage of different useful minerals.

\section{Conclusion}

17 samples of alluvial sands were collected in Lokoundjé and some of its affluent, for environmental and sedimentological study of alluvial deposits around Bipindi. From the coarse and fine grain size of these sands, three aspects of quartz sand grains emerge. The unworn and angular grains are dominant and show proximal origin sedimentation. Moreover, the absence of round grain matt reflects the absence of aeolian transport because of the forest cover. Pebbles collected in Tyango River are very little blunting, dissymmetrical and slightly flattened; they give evidence of a short haul. Heavy minerals consist of andalusite, zircon, monazite, biotite, green hornblende, zoisite and kyanite. They come from two vending areas, the plutonic and metamorphic formations. In term of economic mineralization, the conditions for setting up gold are good; some panning in the alluvium will be needed to attest it. Nevertheless we do already have discreet presence of topaz and monazite. Large amounts of zircon and garnet were also obtained. Detailed investigations should be carried out in geochemistry and petrography in order to elucidate the nature of the hidden minerals in the great quantity of opaque oxides or minerals.

\section{Conflicts of Interest}

The authors declare no conflicts of interest regarding the publication of this paper.

\section{References}

[1] Segalen, P. (1967) Soils and Geomorphology of Cameroon. Cah. ORSTOM, Ser. 
Pedol., V, 187-203.

[2] Njike Ngaha, P.R. (1984) Contribution to the Geological, Stratigraphic and Structural Study of the Edge of the Atlantic Basin in Cameroon. 3rd Cycle Thesis, Fac. Sci. Univ. Yaounde, $131 \mathrm{p}$.

[3] Kue Petou, R.M., Owona Angue, M.L., Njingti, N. and Manguelle-Dicoum, E. (2017) 3D Modelling from New and Existing Gravity Data of an Intrusive Body in the Northern Part of Kribi-Campo Sub-Basin in Cameroon. International Journal of Geosciences, 8, 984-1003. https://doi.org/10.4236/ijg.2017.88056

[4] Toteu, F.S.M., Van Schmus, W.R., Penaye, J. and Nyobe, J.B. (1994) U-Pb and Sm-Nd Evidence for Eburnean and Pan-African High Grade Metamorphism in Cratonic Rocks of Southern Cameroon. Precambrian Research, 67, 321-347. https://doi.org/10.1016/0301-9268(94)90014-0

[5] Vicat, J.P., Léger, J.M., Nsifa, E.N., Piguet, P., Nzenti, J.P., Tchameni, R. and Pouclet (1996) Distinction Congo Craton in South West Cameroon Diabase Two Episodes Introducing the Eburnean Orogenic Cycles (Paleo Proterozoic) and the Pan-African (Neoproterozoic). C.R. Acad. Sc, Paris, T. series IIa, 575-582.

[6] Eno Belinga, M.S. (2001) Geological History of Cameroon, Cameroonians Are Building Classics, 21.

[7] Criaud (1992) Geography of Cameroon. Ed HATIER. Pp 102. From Martonne, E. (1942). New Global Map of Aridity. Ann. Geog, 241-250.

[8] Atlas of Africa and Cameroon (2010). Editions du Jaguar, 82 p.

[9] Olivry, J.C. (1986) Rivers in Cameroon. Hydrological Monograph. ORSTOM. $\mathrm{N}^{\circ}$ Ed MESRES ORSTOM, 733 p.

[10] Martin, D. (1967) Géomorphologie et sols ferrallitiques dans le Centre Cameroun. Cah. ORSTOM, sér. pédol, V, 189-218.

[11] Bilong, P. (1988) Genése et développement des sols ferrallitiques sur syénites alcalines potassiques en milieu forestier du Centre-sud Cameroun. Comparaison avec les sols ferrallitiques développés sur roches basiques. Thèse d'état, Universite Yaoundé, 367 p.

[12] Dieudonné BITOM et Boris VOLKOFF (1993) Altération déferruginisante des cuirasses massives et formation des horizons gravillonnaires ferrugineux dans les sols de l'Afrique Centrale humide. C. R. Acad. Sci. Paris, t. 316, Série II, 1447-1454.

[13] Bekoa, E. (1994) Etude pétrologique et géochimique d'une couverture pédologique en zone forestiere de l'extrême Sud-Cameoun: Relation avec la dynamique du fer. These Doctorat 3éme cycle, Universite Yaounde I, 187 p.

[14] Nguetnkam, J.P. (1994) Etude d'une toposéquence de sols sur granite dans la région de Mvangan (Sud Cameroun). Caractérisation de domaines de pédogenèse différenciés. Thèse $3 \mathrm{e}$ cycle, Fac. Sci. Univ. Yaoundé, 165 p.

[15] Lerouge, C., Cocherie, A., Toteu, S.F., Penaye, J., Milesi, J.P., Tchameni, R., Nsifa, N.E., Fanning, C.M. and Deloule, E. (2006) Shrimp U/Pb Zircon Age Evidence for Paleoproterozoic Sedimentation and 2.05Ga Syntectonic Plutonism in the Nyong Group, South-Western Cameroon: Consequences for the Eburnean-Transamazonian Belt of NE Brazil and Central Africa. Journal of African Earth Sciences, 44, 413-427. https://doi.org/10.1016/j.jafrearsci.2005.11.010

[16] Ganno, S., Moudioh, C., Nzina Nchare, A., Kouankap Nono, G.D. and Nzenti, J.P. (2015) Geochemical Fingerprint and Iron Ore Potential of the Siliceous Itabirite from Palaeoproterozoic Nyong Series, Zambi Area, Southwestern Cameroon. Resource Geology, 66, 71-80. https://doi.org/10.1111/rge.12081 
[17] Maurizot, P., Abessolo, A., Feybesse, A., Johan, V. and Lecomte, P. (1986) Etude et prospection minière du sud-Ouest Cameroon. Sythèse des travaux de 1978 á 1995. 85-CMR 066 BRGM.

[18] Nedelec, A., Minyem, D. and Barbeye, P. (1993) High Pressure-High Temperature. Anatexis of Archaean Tonalitic Gray Gneisses: The Eséka migmatites, Cameroon. Precambrian Research, 62, 191-205. https://doi.org/10.1016/0301-9268(93)90021-S

[19] Ngo Bidjeck, L.M. (2004) The Alteration of Basic and Ultrabasic Rocks of Southwest Cameroon and Metallogenic Implications. If the Abiété Yenjok Complex. Thesis Doct./PhD Univ. Yaounde I, 267 p.

[20] Minyem, D. and Nedelec, A. (1990) Origin and Evolution of the ESEKA Gneisses (Cameroon) Achaean TTG Reworked in the Pan African Mobile Belt. 21-24.

[21] Minyem, D. (1994) Contribution to the Study of Structural and Metamorphic ESEKA-Makak Sector. 3rd Cycle Thesis, Department Nyong and Kelle, Univ. Yaounde I, $166 \mathrm{p}$.

[22] Tchameni, R. (1997) Géochimie et géochronologie des formations de l'Archéen et du Paléoprotérozoïque du Sud-Cameroun (Groupedu Ntem, craton du Congo). Unpublished Thesis, Univ. Orléans, 395 p.

[23] Soh, L.T., Marvine, N.T., Wei, C., Ganno, S., Ngnotue, N., Kouankap, G.D., Shaamu J.S., Zhang and Nzenti, J.P. (2018) Geology and Geochemical Constrains on the Origin and Depositional Setting of the Kpwa-Atog Boga Banded Iron Formations (BIFs), Northwestern Congo Craton, Southern Cameroon. Ore Geology Reviews, 95, 620-638. https://doi.org/10.1016/j.oregeorev.2018.03.017

[24] Duplaix, S. (1958) Microscopic Determination of Mineral Sands. 9th Edition, Poly. Ch Beranger, Paris, $96 \mathrm{p}$.

[25] Parfernoff, A., Pomerol, C. and Toureng, J. (1970) The Mineral Grains: Study Methods and Determination. House \& Co., Paris, 571 p.

[26] Chamley, A. (1987) Sedimentology. Wiley, Collection Geosciences, Paris, 175 p.

[27] Cailleux and Tricart (1959) Distinction of Marine and Fluvial Sands. Bulletin de la Société géologique de France, No. 5, 125-138.

[28] Berthois, L. (1978) Sedimentological Study of Loose Rock. Dion Editors, Place de l'Odéon 75006, Paris VI, 35-44.

[29] Futchbauer, H. (1974) Sediments and Sedimentary Rocks. Halsted Press, London.

[30] Evzerov, V.Ya. (2001) Placer Deposits as Unique Training in the Baltic Shield Loose Cover. Lithology and Minerals Resources, 36, 1009-1115. https://doi.org/10.1023/A:1004818332336

[31] Mc Leod, C.R.S.R. and Morrison (1995) Placer Gold and Platinum- and in Geology Types of Mineral Deposits in Canada. Geological Survey of Canada, Geology of Canada, No. 8, 26-36.

[32] Levson, V.M. (1995) Surficial Placers, in Selected British Columbia Mineral Deposit Profiles, Volume Metallics and Coal. British Columbia Ministry of Energy of Employment and Investment, Open File 1995-20, 21-23.

[33] Michael, J. and Marcoux, E. (2008) Geology of Mineral Resources, Geological Association of Canada. Natural Resources and Wildlife Quebec, Quebec Government, $667 \mathrm{p}$. 